\title{
The Impact of Foreign Capital Inflows on Agriculture Development and Poverty Reduction: Panel Data Analysis for Developing Countries
}

\author{
Furqan Sikandar ${ }^{1}$, Vasilii Erokhin $\left.{ }^{2} \mathbb{(}\right)$, Hongshu Wang ${ }^{1, *}$, Shafiqur Rehman ${ }^{3}$ and Anna Ivolga $4(\mathbb{D}$ \\ 1 College of Economics and Management, Northeast Forestry University, Harbin 150040, China; \\ furqansikandar@nefu.edu.cn \\ 2 School of Economics and Management, Harbin Engineering University, Harbin 150001, China; basilic@list.ru \\ 3 Business School, University of Central Punjab, Lahore 54000, Pakistan; shafiqur.rehman@ucp.edu.pk \\ 4 Faculty of Social and Cultural Service and Tourism, Stavropol State Agrarian University, \\ 355017 Stavropol, Russia; annya_iv@mail.ru \\ * Correspondence: nefuwhs@nefu.edu.cn; Tel.: +86-159-4600-2021
}

Citation: Sikandar, F.; Erokhin, V.; Wang, H.; Rehman, S.; Ivolga, A. The Impact of Foreign Capital Inflows on Agriculture Development and Poverty Reduction: Panel Data Analysis for Developing Countries. Sustainability 2021, 13, 3242. https:// doi.org/10.3390/su13063242

Academic Editor: Jungho Baek

Received: 8 February 2021

Accepted: 11 March 2021

Published: 16 March 2021

Publisher's Note: MDPI stays neutral with regard to jurisdictional claims in published maps and institutional affiliations.

Copyright: (c) 2021 by the authors. Licensee MDPI, Basel, Switzerland. This article is an open access article distributed under the terms and conditions of the Creative Commons Attribution (CC BY) license (https:// creativecommons.org/licenses/by/ $4.0 /)$.

\begin{abstract}
Combating poverty through the development of agricultural production and providing rural people with new employment and income opportunities in agriculture has become one of the major concerns of both policymakers and scholars worldwide. In many developing countries, government policies have failed to achieve the desired poverty alleviation goals due to the lack of financial resources. Despite that, few comprehensive studies have so far unambiguously identified the effects of the exogenous factor of capital inflows on the level of poverty and agriculture development. In this paper, the authors attempt to shed light on the poverty-agriculture-capital trilemma pattern by revealing the impacts of different types of capital inflows on the parameters of poverty reduction and agriculture development. The panel unit root test and pool mean group estimation techniques were employed for observing the short-term and long-term linkages between dependent and explanatory variables across fourteen developing economies of Latin America, Asia, and Eastern Europe. It was revealed that poverty reduction could be positively affected by an increase in the values of agricultural exports, foreign direct investment, foreign development assistance, and remittances received from migrant workers. The level of agriculture could be improved by deeper integration of developing economies to global food supply chains as either suppliers or consumers of food and agricultural products.
\end{abstract}

Keywords: poverty; agriculture development; pooled mean group; foreign capital inflows

\section{Introduction}

Eradicating poverty and ensuring food security by promoting sustainable growth of agricultural production are among the core United Nations' Sustainable Development Goals (SDGs) [1] to be reached by 2030. They are systematically linked with each other as well as with the remaining fifteen SDGs, and thus they formulate the vision of sustainable development of the world over the next decade [2]. Unfortunately, despite the efforts of the international community to combat poverty and food insecurity, the number of undernourished people has resumed growth after a steady decline during the 1990-2000s [3]. In 2015, approximately 736 million individuals lived on less than USD \$1.90 per day [4]. Based on this revelation, the World Bank established the goal to eradicate high poverty levels by 3\% by 2030 . However, even before the world was hit by the COVID-19 outbreak in 2020, the pace of global poverty reduction had been decelerating. The Food and Agriculture Organization (FAO) reports that over 820 million people in the world suffer from hunger, while about two billion people experience moderate or severe food insecurity [5]. According to the United Nations World Food Program (WFP) [6], the economic impact of the pandemic 
could result in doubling the number of people suffering acute hunger by the end of 2020 . Poverty and malnutrition have been particularly exacerbating in developing countries, owing mainly to increases in food insecurity in Latin America, Asia, and Sub-Saharan Africa [7,8]. The WFP [6] expects the most substantial increase in the number of poor people suffering acute hunger to happen across least developed and developing economies that are net importers of food and agricultural products. Therefore, there is a strong need to find a workable (and appropriate in these new conditions) resolution to poverty and food insecurity problems to avoid a global crisis.

Agriculture development is generally acknowledged to be the primary solution to poverty reduction, particularly across the developing part of the world [9-12]. Four decades ago, in his Nobel Prize lecture, Theodore Schultz [13] said that "the majority of the people in developing countries earn their income from the agriculture sector", and this situation has not changed much since then. The agriculture sector is an important source of employment in many developing countries. Agricultural production is the main source of income in rural areas, it provides major staple foods for the rural poor, and accounts for a substantial proportion of GDP. Furthermore, agriculture also contributes up to $25 \%$ of the urban population's livelihood source [14]. According to Ameh et al. [15], the goals of poverty reduction and providing food to 9.7 billion projected populations by 2050 can only be achieved through the development of agricultural production in developing countries.

Despite the importance of the agricultural sector for the economic well-being in developing countries, the majority of agricultural producers still practice conventional farming and hand labor [16]. Such practices not only reduce the productivity of farming but also increase the cost of production. For this reason, Santangelo [17], Ssozi et al. [18], and Arvin and Barillas [19], among others, considered foreign capital inflows an essential factor of agriculture productivity and income of rural dwellers that both could be improved through providing financial resources, advanced technologies, machinery, and farming skills. The United Nations Conference on Trade and Development (UNCTAD) [20] recognized a need for a substantial increase in investment in the expansion of agricultural production to meet the SDGs on combating hunger and poverty in developing countries. There is a considerable investment gap of USD $\$ 2.5$ trillion in the areas of water use and irrigation, sanitation, and infrastructure for agricultural production in developing countries [20]. The share of government expenditure in the agricultural sector fell from $0.42 \%$ in 2001 to $0.28 \%$ in 2018, while aid to agriculture in developing countries declined from $25 \%$ of all donors sector-allocable aid in the mid-1980s to only 5\% in 2018 [8]. Therefore, the United Nations encourages higher foreign capital inflows such as remittances, foreign direct investment (FDI), foreign borrowing, official development assistance (ODA) to mitigate the deficiency of financial resources in agriculture.

There is an array of studies that address the effects of particular types of foreign capital inflows on either poverty or the volume of agricultural output. According to the Institute of International Finance [21] and the World Bank [22], key categories of capital inflows are foreign direct investment, external borrowing, foreign trade, remittances, and foreign aid. Petrikova [23], Slimane et al. [24], and Magombeyi and Odhiambo [25] considered foreign capital inflows appropriate channels for combating poverty and ensuring agriculture development, however, they all have two-side effects, either positive or negative, on both poverty and agriculture. One can never identify clearly which sector will gain and which sector will lose from foreign capital inflows. For instance, as regards remittances, De Brauw [26] found that remittances played an essential role in changing the structure of the agricultural sector and improving standards of living in rural areas by providing monetary and nonmonetary benefits to recipient countries, rural communities, and households. On the other hand, Taylor et al. [27] revealed a negative impact of remittances in increasing agricultural output and suggested that productivity in rural areas could be affected differently depending on the level of development of particular territories and the intensity of out-migration.

The influences of other types of capital inflows on both poverty and agriculture development have also been assessed from various positions and thus have received 
controversial results. Thus, according to Senadza et al. [28], foreign aid programs have established a good mechanism of transfer of money from international organizations and developed countries to developing countries, which has substantially contributed to poverty alleviation across the developing world. The baseline of this reasoning (also emphasized by Gupta [29], Islam [30], and Levy [31]) rests on the assumption that foreign aid augments domestic resources and supplements domestic saving and in such a way improves well-being in all segments of society, including that of poor people. At the same time, when studying relationships between foreign aid and poverty reduction in the least developed, middle-income, and higher-middle-income countries, Chong et al. [32], Azam et al. [33], and Wrangberg [34] found substantial diversity in anti-poverty effects of aid from strong direct influence in more developed economies to no meaningful relationship in low-income countries.

Therefore, it is safe to assume that foreign aid on its own has no explicit impact on poverty reduction except when it is allowed to interact with other variables for which a more significant effect is recorded [35]. This could be the case of reducing rural poverty when foreign aid inflows are directed to the development of the agricultural sector. However, there is also a discrepancy with the understanding of foreign aid's effects on agricultural production taking into account a great deal of heterogeneity among developing countries. For instance, Kaya et al. [36] reported a significant positive relationship between aid and growth of agricultural production and Mary et al. [37] demonstrated how agriculture aid inflows contributed to the development of various spheres related to agriculture, including water management, education and research, and agricultural policies and services, while Philip [38] and Ijaiya and Ijaiya [39] expressed a rather pessimistic view that total aid might be not effective for poverty alleviation and agriculture development. As a form of government-to-government subsidy, aid is not always efficiently translated into transfers of resources to poor people, particularly taking into account the undiversified institutional structure of the economy and ineffective public governance in many developing countries [40].

As regards foreign direct investment, Fofana et al. [41], Ikenze et al. [42], and Kumar and Gopalsamy [43] revealed that FDI inflows led to improved systems, know-how, technology, and management practices in recipient developing countries. Controversially, some studies have not found any effect of FDI on poverty alleviation, for example, Gohou and Soumaré [44] in West Africa and Huang et al. [45] in Taiwan found that FDI had no significant effect on the reduction of poverty.

Therefore, notwithstanding the interest in revealing the poverty reduction potential of foreign capital inflows, the research in this area is still scarce in terms of understanding the impacts of individual types of inflows on eradicating poverty and establishing foundations for sustainable development of agricultural production. Moreover, few studies have ever assessed the combined effects of foreign aid, agricultural trade, external borrowing, foreign investment, and remittances on poverty reduction and agriculture development simultaneously. Additionally, there is a lack of international studies that capture and compare cases of various developing countries worldwide instead of focusing on one location. In an attempt to contribute to the solution of these problems, this study aims to reveal the impacts of six types of foreign capital inflows on the parameters of poverty reduction and agriculture development in the short-term and long-term perspectives across fourteen developing economies of Latin America, Asia, and Eastern Europe.

\section{Materials and Methods}

\subsection{Selection of Variables}

As far as this study aims at evaluating the effectiveness of capital inflows in poverty alleviation and improvement of agricultural production, the impacts of foreign capital inflows on dependent variables of poverty reduction (POV) and agriculture development (AGR) are investigated separately along six parameters (Table 1). We focused on major capital-related factors of both poverty reduction and agriculture reported by the Institute 
of International Finance [21], the World Bank [22], the United Nations [8], and the Peterson Institute for International Economics [46].

Table 1. Variables included in the study.

\begin{tabular}{cccccc}
\hline & Dependent Variables & & \multicolumn{2}{c}{ Independent Variables } \\
\hline Identifier & Definition & Measure Unit & Identifier & Definition & Measure Unit \\
\hline POV & Poverty reduction & USD \$ million & AGRX & Exports of agricultural raw materials & USD \$ million \\
AGR & Agriculture development & USD \$ million & AGRM & Imports of agricultural raw materials & USD \$ million \\
& & & NODA & Net official development assistance & USD \$ million \\
& & & NFDI & Net foreign direct investment & USD \$ million \\
& & & NEXD & Net external debt & USD \$ million \\
& & & NRMT & Net remittances & USD \$ million \\
\hline
\end{tabular}

Source: Authors' development.

To show the overall effect of agricultural trade on the development of agricultural production and the reduction of poverty, we utilized the parameters of exports of agricultural raw materials (AGRX) and imports of agricultural raw materials (AGRM). While we used net values for remaining four independent variables, exports and imports were estimated separately rather than aggregated as parameters of net trade or trade turnover. This was done to test individual effects of exports and imports on poverty (where the influence of agricultural imports could be stronger than that of exports due to food security policy) and agriculture (where exports more significantly affect incomes of farmers compared to imports). According to Reyer et al. [47], high reliance on imports imposes a threat to sustainable availability and accessibility of food products on the market. Both poor households and farmers experience severe effects of food prices fluctuations as large percentages of households' and state budgets' incomes are spent on food imports. There is also a dependence of developing countries with their limited resources on a small range of food products exported to a few markets [48,49]. The United Nations [7] acknowledges the disruptions in food supply chains and food trade to be one of the major factors of poverty and food insecurity in Sub-Saharan Africa, Latin America, and Southeast Asia [3]. Following Deuss [50], Martin and Anderson [51], and Hendrix [52], among others, we assume that the parameters of food trade must be taken into account when studying poverty and agricultural development across developing countries. The choice of AGRX and AGRM variables well correlates with the recommendations of Huseynov [53], Erokhin and Gao [3], and Puma et al. [54], who used food trade as a variable to identify short-term and long-term effects on both the development of domestic agriculture and the reduction of poverty in the economy.

One of the most important capital inflows which helps alleviate poverty in developing countries is foreign aid [55-57]. The effects of foreign aid range from poverty alleviation and combating food insecurity to a broader spectrum of issues, including strengthening domestic food production, the establishment of agriculture institutes, and the promotion of agriculture development [58-60]. Both the World Bank and the OECD strongly focus on the role of aids in support of agriculture development and poverty reduction in developing countries [61,62]. However, since Philip [38], Ijaiya and Ijaiya [39], and Chong et al. [32] found low or even negative effect of foreign aid on poverty alleviation and development of domestic agricultural production, we included NODA variable (net official development assistance) in our study to test the relationship between foreign aid and the parameters of poverty and agriculture development.

Net foreign direct investment (NFDI) is commonly used as a macroeconomic variable in panel time series estimation [63-65]. Even though Chaudhuri and Banerjee [66], Nedumaran and Manida [67], and Li and Wahl [68] revealed positive impact of FDI on the productivity of farming, combating food insecurity, and reduction of poverty across developing countries, the effects of FDI can be indirect [69,70] or even negative [45,71]. Therefore, the links between NFDI and POV and AGR must be further tested. 
Another capital inflow is net external debt (NEXD variable) which plays an important role in the utilization of local resources to achieve the overall national economic goals [28]. Along with per capita GNP and headcount index, the value of net external debt is commonly used as a determinant and measure of poverty. Macroeconomic stability in developing countries is at risk of being disturbed by an increase in external debt [72], which can negatively affect consumption, capital formation, and liquidity [73]. Heavy debt burden could result in a higher level of poverty in both short-run and long-run perspectives [74,75], reduce social expenditure and investment [76], deter economic growth [77], and even result in higher mortality rates and lower education enrolments as indicators of poverty and income inequality [76]. However, there are direct relationships that should be tested since they demonstrate how recipient countries utilize their debts to combat poverty by pouring money into education or health care or accelerate the development of the agricultural sector by investing in production or supporting local farmers.

The reason for the inclusion of NRMT variable in the study is that the impact of remittances on agriculture development and poverty is ambiguous. On the one hand, a shortage of labor in rural areas caused by out-migration negatively affects agricultural production. On the other hand, the inflow of remittances can increase agricultural output by investment in machinery or technological improvements $[78,79]$ and thus initiate structural changes in the agricultural sector [26]. As most of least developed countries and many developing economies depend on agricultural production, such transformations can positively affect economic growth and contribute to poverty alleviation $[27,80]$. Foreign remittances not only improve productivity but also provide nonmonetary and monetary benefits to recipient households, communities, and countries [81,82]. Remittances are also used for repayment of bank loans, purchasing food or clothes, and paying for education and health care [83]. Despite contradictory effects of labor outflow from rural areas on agriculture development, Thieme and Wyss [84], Wagle and Devkota [85], and Vargas et al. [86] commended the strategy of sending family members for foreign employment as one of the ways to reduce poverty and diversify the sources of income.

\subsection{Models and Analytical Framework}

An econometric model is developed where poverty is the dependent variable, while net foreign direct investment, net remittances, net external debt, net official development assistance, and GDP deflator are explanatory variables along with error term $\left(\mu_{i, t}\right)$, which captures the factors not included in the model. The intercept of $\alpha_{1}$ and slope coefficients $\alpha_{2-8}$ of respective variables are given in the Model 1 (Equation (1)).

$\mathrm{POV}_{i, t}=\alpha_{1}+\alpha_{2} \mathrm{NFDI}_{i, t}+\alpha_{3} \mathrm{NREM}_{i, t}+\alpha_{4} \mathrm{NEXD}_{i, t}+\alpha_{5} \mathrm{NODA}_{i, t}+\alpha_{6} \mathrm{GDPDF}_{i, t}+\alpha_{7} \mathrm{AGRX}_{i, t}+\alpha_{8} \mathrm{AGRM}_{i, t}+\mu_{i, t}$

The Model 2 (Equation (2)) is related to observe the impact of capital inflows on agriculture development. The explanatory variables are all foreign capital inflows, where $\beta_{1}$ is the intercept of the model and $\beta_{2-7}$ are slope coefficients of the respective variables. The error term is denoted by $\vartheta_{i, t}$, which captures unknown factors. The subscript $(i, t)$ shows the panel data is used for analysis.

$\mathrm{AGR}_{i, t}=\beta_{1}+\beta_{2} \mathrm{NFDI}_{i, t}+\beta_{3} \mathrm{NREM}_{i, t}+\beta_{4} \mathrm{NEXD}_{i, t}+\beta_{5} \mathrm{NODA}_{i, t}+\beta_{6} \mathrm{AGRX}_{i, t}+\beta_{7} \mathrm{AGRM}+\vartheta_{i, t}$

In addition to the six explanatory variables, Model 1 also includes a GDP deflator (GDPDF) to correct income inflows for inflation. This approach corresponds with previous studies of Magombeyi and Odhiambo [25,70], Abdullah [63], and Amartey [87], who investigated the relationship between capital inflows and poverty. In both Model 1 and Model 2, NODA includes the disbursements of loans, NEXD includes public and publicly guaranteed long-term debt, and NFDI includes the sum of equity capital.

The dynamic panel data model provides dynamic effects of change in explanatory variables upon current and future values of independent variables. So, one unit increase in the explanatory variable has an immediate impact on the depending variable. This effect will continue for a longer period which determines the long-run effect [88]. In our 
study, two models were analyzed independently. Each model has short-run as well as long-run effects. The results of one model cannot affect the results of another model, which means that the results of additional variables have an independent impact on poverty reduction and agriculture development. Commonly, the policymakers are concerned to observe the impact of explanatory variables on dependent variables in the short-run as well as in the long-run. The short-run effects measure the immediate impact of the variables. These effects in the short run may not be significant, but a sign of the estimated coefficient determines the direction of the variables. The main advantage of observing short-run impact is that it provides the error correction term which shows how much of the disequilibrium can be corrected in the long run. In analyzing time series data, the most crucial problem is that of heterogeneity because separate regressions are estimated for each country and resulting parameters would be different. Short-run parameters of foreign capital inflows vary across the cross-sections, while long-run ones are constrained to be homogenous. According to Pesaran et al. [89], such heterogeneous bias in a dynamic panel can be solved by applying the pooled mean group estimation (PMG) approach, which we employed to measure intercepts and short-run and long-run coefficients of the variables. The PMG technique provides consistency and efficiency by pooling heterogeneous dynamic relationships. It thus allows the parameters to be variant in the short-run but homogenous in the long-run.

We applied the PMG estimation technique to observe the short-run and long-run effects of independent variables on dependent ones. In the Equation (3) for panel ARDL, poverty reduction and agriculture development are dependent variable and their lags are used as regressors, while $X_{i, t}$ variables include all explanatory variables.

$$
Y_{i, t}=\sum_{j=1}^{p} \delta_{i j} Y_{i, t-j}+\sum_{j=1}^{q} \gamma_{i j} X_{i, t-j}+\mu_{i}+\varepsilon_{i, t}
$$

The selection of lag length of the model is based on Akaike information criterion (AIC). The lag length can be observed by taking maximum lags and then observing the AIC values selecting the model where the AIC value is at minimum. Alternatively, the lag length can be selected automatically by using the software. The model selection criteria can be viewed through numerical values of the AIC. For observing short-run and long-run effects, the PMG estimator provides the results separately. The value of error correction term is also given to observe the convergence of the variables in the long run. The specific model for the PMG estimator is given in Equation (4).

$$
\Delta Y_{i t}=\theta_{i}\left(Y_{i, t-1}-\beta_{i}^{\prime} X_{i, t-1}\right)+\sum_{j=1}^{p-1} \delta_{i j} \Delta Y_{i, t-j}+\sum_{j=1}^{q-1} \gamma_{i j} \Delta X_{i, t-j}+\mu_{i}+\epsilon_{i t}
$$

The model can be written in deviation form as follows (Equation (5)):

$$
\Delta y_{i t}=\theta_{i}\left(y_{i, t-1}-\beta_{i}^{\prime} x_{i, t-1}\right)+\sum_{j=1}^{p-1} \delta_{i j} \Delta y_{i, t-j}+\sum_{j=1}^{q-1} \gamma_{i j} \Delta x_{i, t-j}+\mu_{i}+\epsilon_{i t}
$$

The variable $y_{i t}$ represents dependent variable, whereas, $x_{i, t-j}$ shows the vector of explanatory variables and $\theta_{i}$ shows the error correction term, which elaborates the convergence or divergence of the model in the long-run. The convergence or divergence depends on the sign of the numerical value of the error correction term. If the value of the error correction term becomes negative, then we can say that there exists long-run relationship among the variables and convergence towards equilibrium. $\beta_{i}^{\prime}$ denotes long-run parameters.

To test the stationarity of the variables, the Levin-Lin-Chu test (LLC) and the ImPesaran-Shin test (IPS) were applied. The LLC test formulated by Levin et al. [90] can be treated as a pooled Dickey-Fuller or augmented Dickey-Fuller test potentially with different time lags across the units of the panel [91]. One of the weak points of the LLC test 
is that the coefficient is homogeneous across the cross-sections. The IPS test elaborated by Im et al. [92] is the extension of the LLC test where lagged dependent variables are used as regressors. In the IPS test, it is presumed that all series are non-stationary under the null hypothesis and a fraction of the series is stationary under the alternative hypothesis [91]. It is different from the LLC test, in which all series are supposed to be stationary under the alternative hypothesis. Thus, the IPS test provides individual results of each cross-section.

Multicollinearity is a crucial problem in time series data analysis. One of the solutions to this problem is to combine cross-section data and time-series data (known as pooling the data) [93]. The use of dynamic panel data models in this study allows us to minimize the problem of multicollinearity. Another problem in analyzing time series data is that of heterogeneity because separate regressions are estimated for each country and resulting parameters could be different. We approached solving this problem by using the PMG technique in dynamic panel data analysis. The employment of this method allowed the parameters to vary in the short run but stay homogenous in the long-run and thus provided the consistency and efficiency of the analysis by pooling heterogeneous dynamic relationships.

\subsection{Countries and Data}

To reveal diverse effects of foreign capital inflows on poverty and agriculture development across a variety of macroeconomic environments, the study was performed in the cases of developing countries representing Latin America and the Caribbean, South Asia, East Asia and Pacific, Central Asia, and Europe (Figure 1). The choice of countries is determined by several criteria, the successive application of which allowed us to establish an array of fourteen states. First, in the databases of the World Bank's World Development Indicators [94] and the Penn World Table [95], we selected developing countries for which the data was available for the entire period of twenty-nine years from 1990 through 2018. Second, among them, we addressed the groups of lower-middle-income and uppermiddle-income countries (according to the World Bank's Country and Lending Groups classification [96]) to capture the diversity of income distribution patterns and poverty levels. Poverty is measured by the household consumption expenditure as a percentage of GDP and thus captures income poverty. The positive coefficient of explanatory variables implies that poverty is increasing while the negative one implies that poverty is reducing. Then, third, to reflect the factor of agriculture development, in the two groups, we selected countries in which both the average share of agriculture in GDP and the average share of the rural population in total population were the highest in 1990-2018.

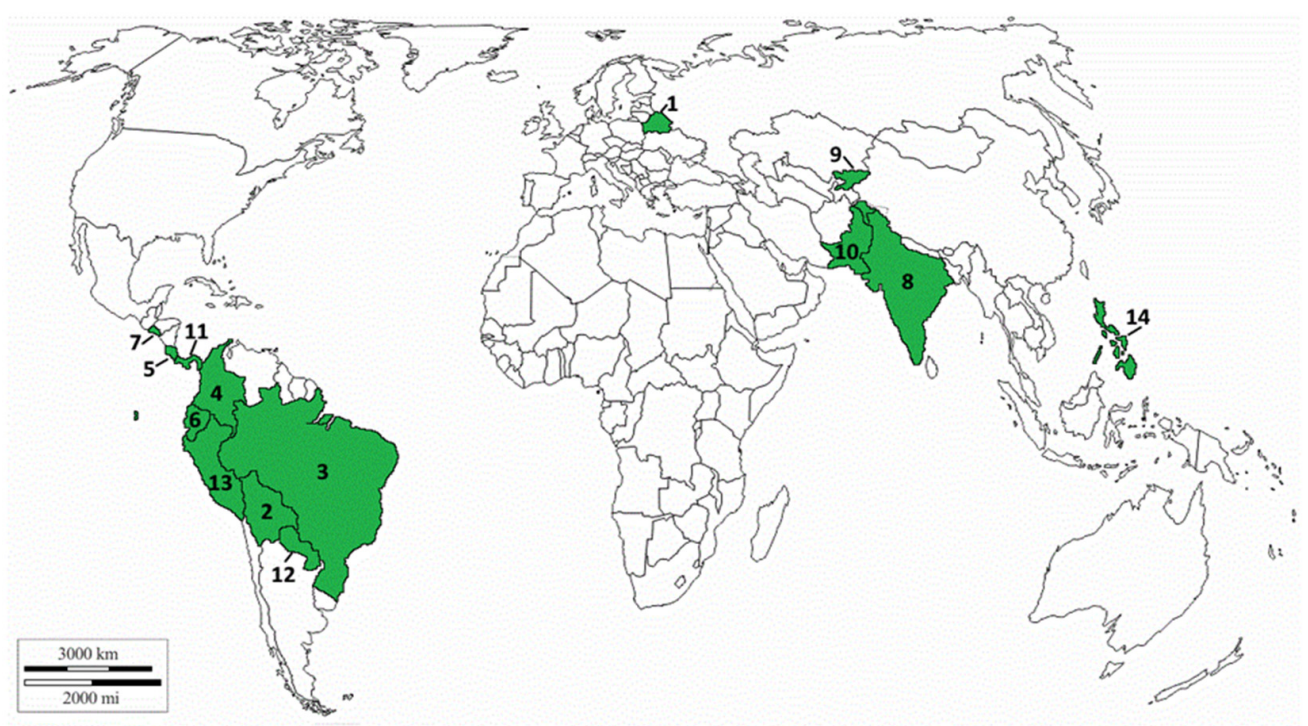

Figure 1. Countries included in the study. Note: 1 = Belarus; $2=$ Bolivia; $3=$ Brazil; $4=$ Colombia; $5=$ Costa Rica; $6=$ Ecuador; 7 = El Salvador; 8 = India; 9 = Kyrgyzstan; 10 = Pakistan; 11 = Panama; 12 = Paraguay; 13 = Peru; $14=$ Philippines. Source: authors' development. 


\section{Results}

\subsection{Unit Root Tests}

Whether the data is stationary or non-stationary has great implications on the validity of the results. When data become non-stationary then the resulting regression would be spurious, which means that test statistics and estimators are misleading. The LLC test and the IPS test were applied to assess the stationarity of the selected variables. Four variables (AGRX, AGRM, POV, and NEXD) were found to be stationary at a $5 \%$ level of significance with both intercept and intercept and trend, while other variables were stationary using the LLC and the IPS tests. NRMT was recognized as not stationary in both tests (Table 2).

Table 2. Unit root test results at the level.

\begin{tabular}{|c|c|c|c|c|}
\hline \multirow{2}{*}{ Variables } & \multicolumn{2}{|c|}{ LL Test } & \multicolumn{2}{|c|}{ IPS Test } \\
\hline & Intercept & Intercept and Trend & Intercept & Intercept and Trend \\
\hline \multirow[t]{2}{*}{ AGR } & $-2.94249^{*}$ & 0.09350 & -0.77757 & -0.93946 \\
\hline & $(0.0016)$ & $(0.5371)$ & $(0.2184)$ & $(0.1737)$ \\
\hline \multirow[t]{2}{*}{ AGRM } & $-3.80994 *$ & -1.56185 & $-4.28285 *$ & -2.03753 * \\
\hline & $(0.0010)$ & $(0.0592)$ & $(0.0000)$ & $(0.0208)$ \\
\hline \multirow[t]{2}{*}{ AGRX } & $-3.65042 *$ & $-2.48525 *$ & -2.19684 * & $-3.30145 *$ \\
\hline & $(0.0001)$ & $(0.0065)$ & $(0.0140)$ & $(0.0005)$ \\
\hline \multirow[t]{2}{*}{ GDPDF } & 165.41700 & 196.32500 & $-161.30500 *$ & $-190.60700 *$ \\
\hline & $(1.0000)$ & $(1.0000)$ & $(0.0000)$ & $(0.0000)$ \\
\hline \multirow[t]{2}{*}{ NEXD } & $-3.18267 *$ & -3.03691 * & $-6.78021 *$ & $-7.39445 *$ \\
\hline & $(0.0007)$ & $(0.0012)$ & $(0.0000)$ & $(0.0000)$ \\
\hline \multirow[t]{2}{*}{ NFDI } & -0.08494 & -0.15294 & -0.34705 & -2.49021 * \\
\hline & $(0.4662)$ & $(0.4392)$ & $(0.3643)$ & $(0.0064)$ \\
\hline \multirow{2}{*}{ NODA } & 0.78028 & -1.20823 & $-3.97439 *$ & $-4.96772 *$ \\
\hline & $(0.7824)$ & $(0.1135)$ & $(0.0000)$ & $(0.0000)$ \\
\hline \multirow[t]{2}{*}{ NRMT } & 3.31898 & -0.48432 & 6.68296 & 1.17699 \\
\hline & $(0.9995)$ & $(0.3141)$ & $(1.0000)$ & $(0.8804)$ \\
\hline \multirow[t]{2}{*}{ POV } & $-6.86272 *$ & $-9.03847 *$ & -8.38922 * & $-9.40182 *$ \\
\hline & $(0.0000)$ & $(0.0000)$ & $(0.0000)$ & $(0.0000)$ \\
\hline
\end{tabular}

At the second stage, checking of the unit toot test results by implementing the LLC test and the IPS test at first difference demonstrated that all variables included in the study were stationary with both intercept and intercept and trend (Table 3).

\subsection{Selection of Lag Length}

The lag length was based on Akaike information criterion (AIC), which is the source of selecting the best model. The lag length was selected where the values of AIC were at minimum. In both models, the AIC values are minimum, whereas lag length is 2 and the AIC equals 4.73995 for Model 1 and 2.340618 for Model 2 (Table 4).

\subsection{PMG Results for Models 1 and 2}

Model 1 results demonstrated that NRMT, NODA, NFDI, and AGRX had a positive and significant impact on the reduction of poverty, while NEXD and AGRM increased the level of poverty across selected developing economies in the long run (Table 5). The parameter of GDP deflator allowed us to capture a negative but insignificant impact of inflation on poverty. Remittances, foreign direct investment, and foreign aid all have a minor effect on the reduction of poverty. AGRX exerts the most significant influence on reducing poverty as a $1 \%$ increase in exports of agricultural products and raw materials reduces poverty by $2.57 \%$. On the contrary, a consistent $1 \%$ increase in agricultural imports results in an increase in poverty by $0.62 \%$. The volume of external debt can also aggravate the poverty problem, but the NEXD-POV relationship is very weak. A $1 \%$ increase in external borrowing increases poverty by only $0.0005 \%$. 
Table 3. Unit root test results at the first difference.

\begin{tabular}{ccccc}
\hline \multirow{2}{*}{ Variables } & \multicolumn{2}{c}{ LL Test } & \multicolumn{2}{c}{ IPS Test } \\
\cline { 2 - 5 } & Intercept & Intercept and Trend & Intercept & Intercept and Trend \\
\hline AGR & $-5.62452 *$ & $-3.91750 *$ & $-14.96350 *$ & $-15.14490 *$ \\
& $(0.0000)$ & $(0.0000)$ & $(0.0000)$ & $(0.0000)$ \\
AGRM & $-8.93811 *$ & $-7.26622 *$ & $-13.72760 *$ & $-12.43800 *$ \\
& $(0.0000)$ & $(0.0000)$ & $(0.0000)$ & $(0.0000)$ \\
AGRX & $-4.65700 *$ & $-9.83480 *$ & $-15.50100 *$ & $-12.43410 *$ \\
& $(0.0000)$ & $(0.0000)$ & $(0.0000)$ & $(0.0000)$ \\
GDPDF & $177.42200 *$ & $22.14800 *$ & $-340.37500 *$ & $-370.06100 *$ \\
& $(0.0000)$ & $(0.0000)$ & $(0.0000)$ & $(0.0000)$ \\
NEXD & $-12.36230 *$ & $-9.55070 *$ & $-15.56360 *$ & $-13.60100 *$ \\
& $(0.0000)$ & $(0.0000)$ & $(0.0000)$ & $(0.0000)$ \\
NFDI & $-9.36065 *$ & $-7.07752 *$ & $-20.30000 *$ & $-18.51710 *$ \\
& $(0.0000)$ & $(0.0000)$ & $(0.0000)$ & $(0.0000)$ \\
NODA & $-11.92390 *$ & $-10.96100 *$ & $-22.11140 *$ & $-21.10080 *$ \\
& $(0.0000)$ & $(0.0000)$ & $(0.0000)$ & $(0.0000)$ \\
NRMT & $-8.62759 *$ & $-7.87082 *$ & $-8.68004 *$ & $-8.19479 *$ \\
& $(0.0000)$ & $(0.0000)$ & $(0.0000)$ & $(0.0000)$ \\
POV & $-18.69250 *$ & $-11.22580 *$ & $-22.48110 *$ & $-18.34100 *$ \\
& $(0.0000)$ & $(0.0000)$ & $(0.0000)$ & $(0.0000)$ \\
\hline
\end{tabular}

Note: * significance at $5 \%$ level; probability ' $p$-value' is given in parenthesis. Source: authors' calculation.

Table 4. Models 1 and 2: Akaike information criterion.

\begin{tabular}{ccccc}
\hline Model 1 & AIC & Model 2 & AIC & Specification \\
\hline 4 & 4.734995 & 4 & 2.340618 & ARDL $(2,2,2,2,2,2,2)$ \\
3 & 4.916078 & 3 & 2.371264 & ARDL $(1,2,2,2,2,2,2)$ \\
2 & 4.951469 & 2 & 2.494656 & ARDL $(2,1,1,1,1,1,1)$ \\
1 & 4.955179 & 1 & 2.526750 & ARDL $(1,1,1,1,1,1,1)$ \\
\hline
\end{tabular}

Source: authors' calculation.

Model 2 results showed that all variables apart from NRMT had a positive impact on agriculture development in the long run. Agricultural trade exerts the strongest positive effect on the level of agricultural development in the countries included in the study. A $1 \%$ increase in agricultural exports and imports is associated with a growth of agricultural output by $2.55 \%$ and $2.19 \%$, respectively. Foreign aid, foreign direct investment, and external borrowing all have a less significant influence on the development of the agricultural sector in the long-run perspective. The value of remittances received from abroad affects domestic agriculture in a negative way, where a $1 \%$ increase in net remittances depresses agricultural production in a country by $0.0004 \%$.

The adjustment effect is measured by the error correction term. The sign of coefficient determines the convergence and divergence of the variables in the long run. The negative coefficient of error correction shows the deviation from the long-run equilibrium. The ECM coefficient $(-0.517164)$ for short-run Model 1 shows that the deviation from short-run in poverty is corrected by $51.72 \%$ in each year in the long-run. The results are significant at $5 \%$. The coefficient of GDP deflator is also significant at 10\%. The insignificant results show that variables have no impact in the short run, requires longer period of time for effective utilization of resources. In the long run, all the variables have significant impact. In Model-2, the negative coefficient of error correction shows that deviation from the long-run equilibrium in agriculture development is corrected by $19.17 \%$ each year. The variables have an insignificant impact on the dependent variable in the short-run. Only AGRX demonstrated a relatively strong influence on the level of agriculture development at $10 \%$ of significance. The PMG results of the short run are summarized in Appendix A, Table A1. 
Table 5. Models 1 and 2: pooled mean group estimation (PMG) results of long run.

\begin{tabular}{|c|c|c|}
\hline Variable & Model 1 & Model 2 \\
\hline \multirow[t]{3}{*}{ NRMT } & 0.000166 * & $-0.000376^{*}$ \\
\hline & $(0.000051)$ & $(0.000081)$ \\
\hline & $(3.255262)$ & $(-4.601857)$ \\
\hline \multirow[t]{3}{*}{ NEXD } & -0.000491 * & $0.000263 *$ \\
\hline & $(0.000090)$ & $(0.000056)$ \\
\hline & $(-5.456444)$ & $(4.696964)$ \\
\hline \multirow[t]{3}{*}{ NFDI } & $0.000160 *$ & 0.000014 \\
\hline & $(0.000039)$ & $(0.000069)$ \\
\hline & $(4.082803)$ & $(0.209166)$ \\
\hline \multirow[t]{3}{*}{ NODA } & 0.001468 * & $0.004162 *$ \\
\hline & $(0.000708)$ & $(0.001238)$ \\
\hline & $(2.073645)$ & $(3.361366)$ \\
\hline \multirow[t]{3}{*}{ AGRX } & $2.567606^{*}$ & 2.546430 * \\
\hline & $(0.539024)$ & $(0.303899)$ \\
\hline & $(4.763433)$ & (8.379186) \\
\hline \multirow[t]{3}{*}{ AGRM } & $-0.623346^{*}$ & 2.189452 * \\
\hline & $(0.136516)$ & $(0.286933)$ \\
\hline & $(-4.566102)$ & (7.630535) \\
\hline \multirow[t]{3}{*}{ GDPDF } & 0.000851 & \\
\hline & $(0.001082)$ & \\
\hline & $(0.786659)$ & \\
\hline Number of observations & 373 & 373 \\
\hline Time period & 27 years after 2 years & 27 years after 2 years \\
\hline Lag & $\begin{array}{c}\text { lag period } \\
2\end{array}$ & $\begin{array}{c}\text { lag period } \\
2\end{array}$ \\
\hline Sum of squared residuals & 0.938760 & 0.743812 \\
\hline Number of cross-sectional units & 14 & 14 \\
\hline
\end{tabular}

\subsection{Robustness Check}

To check the robustness of the established models, we applied other lag criterion, such as the Schwarz Bayesian information criterion (SBC) and the Hannan-Quinn criterion (HQ), which applicability to testing the robustness of economic variables in developing countries has been demonstrated by many scholars, including by Aronu et al. [97] in Nigeria, Aslam and Lebbe [98] in Sri Lanka, Iqbal Chaudhry et al. [99] in China, Mehrara [100] in Iran, and Badshah and Bulut [101] in BRICS countries. We found that results had no change with the sign and significance of the coefficients. To check if there was an impact of outlying economies, we drop five countries (India, Pakistan, Kyrgyzstan, Belarus, and Philippines) from the data set and run the same model for the remaining nine countries using the PMG technique. The sign and coefficients demonstrated robustness, the magnitude was rather stable and significant. The error correction terms are significant; the negative sign show the convergence towards equilibrium in the long run. The ECM results along with the long-run results of the PMG coefficients are summarized in Appendix B, Table A2.

\section{Discussion}

\subsection{Model 1: Poverty Reduction}

Across fourteen developing economies included in our study, reduction of poverty significantly depends on the inclusion of the domestic agricultural sector in global food supply chains as either exporters or importers of agricultural products and raw materials. The revealed link between the level of poverty and the value of agricultural trade (negative in case of exports and positive in case of imports) well agrees with previous findings of Wood et al. [102], who demonstrated that for agriculture-dependent developing economies both global food chain disruptions and restrictions of food exports could have serious negative consequences for the level of poverty and food insecurity. To alleviate poverty, 
policy measures should be aimed at a possible increase in the value of agricultural exports, as well as a decrease in imports. However, for lower-middle-income economies, the strength of the trade-poverty link has increased in previous years as a decline in food imports has caused a growth in the number of people living below the poverty line and having insufficient food consumption $[3,54]$. This is because in some import-dependent low-income countries, the supply of staple foods for the poor particularly depends on imports. Such agriculture-dependent countries are particularly threatened by disruptions of food supply chains $[103,104]$, that is why for them it is necessary to ensure a stable supply of food and agricultural products from abroad.

In addition to agricultural imports, an increase in external borrowing aggravates the poverty problem. Elbadawi et al. [105] and Were [106] reported that external debt had a significant negative influence on poverty across developing countries, but our analysis suggested this effect to be rather low in higher-income countries. This latter finding of us well correlates with Nguyen et al. [107] who also confirmed that external debt had a negative, but weak impact on the reduction of poverty. In lower-income economies, the negative effect of foreign debt on the level of poverty is stronger. For instance, Ashraf et al. [108] demonstrated that external debt had a negative long-run relationship with the poverty headcount ratio in Asia. Therefore, poverty alleviation measures should involve control of external borrowing and a possible decrease in debt burden, particularly, in lower-middle-income countries.

As regards foreign investment, we found a positive link between an increase in the value of attracted capital inflows and the reduction of poverty which agrees with Ucal [109], who revealed a strong significant relationship between FDI inflows and poverty reduction in 26 developing countries and concluded that FDI supported poverty reduction. A stronger FDI-poverty link in the long-run compared to that in the short-run perspective could demonstrate the fact that the impact of FDI on poverty alleviation is sensitive to time proxy. However, despite the fact that many studies report a significant influence of investment on the reduction of poverty, we estimate this relationship as rather weak. Such a weak effect was also discovered by Ahmad et al. [110] whose results are particularly worth comparing with our findings due to the employment of relatively similar techniques and alike data set in the geographic region thinly represented in our array of countries. It is possible to note the similarity of results, in particular, for India, Pakistan, and the Philippines (all three are lower-middle-income economies, according to the World Bank [96]). However, with an increase in the level of well-being, the direct impact of FDI on poverty reduction decreases, while for less developed and poor countries, the NFDI-POV relationship is strong and direct. This trend of changing strength of the link is visible in our study in the example of upper-middle-income (weaker relationship) and lower-middle-income (stronger relationship) countries of Latin America and the Caribbean that border each other, but are characterized by different economic conditions and the level of development of agricultural production.

Similar ambiguous results characterize the relationship between poverty and foreign aid. It is natural to suggest that an increase in the inflow of foreign aid could benefit poverty alleviation (which is found in our study). Nevertheless, there are contradictory relationships between these two variables, from strongly positive [111,112] to insignificant $[32,34]$ and even negative $[33,113]$. For example, Boone [114] demonstrated that foreign aid could increase consumption, but in a situation of high-income inequality (typical for many least developed and developing countries), such increased consumption did not benefit the poor and thus barely contributed to poverty alleviation. We particularly see weaker NODA-POV relationship in lower-middle-income countries of Latin America and the Caribbean (Bolivia, El Salvador) and Asia (India, Pakistan, Philippines), while that in upper-middle-income economies is stronger. Boone [114] explains this pattern by the fact that in lower-income countries, poverty is caused by structural economic problems rather than a simple shortage of capital. While some poverty relief programs can be effective in the short run, they do not effectively correlate with the basic economic factors that cause growth in the standards 
of living and consumption and thus they have little impact on long-term parameters of human development and investment. Anti-poverty effects of foreign aid could be more visible in upper-middle-income countries, which should encourage long-term development assistance programs. In lower-middle-income economies, targeted short-term poverty and hunger relief programs are more efficient. This emphasizes the need for a more comprehensive study of the potential role of foreign aid and development assistance as tools in changing consumption patterns in both least developed and lower-middle-income economies.

In contrast to the above-discussed types of capital inflows, a positive impact of remittances on the reduction of poverty is commonly accepted [85]. A comprehensive analysis of remittances' effects on the level of poverty in 71 developing countries conducted by Adams and Page [115] showed that foreign remittances significantly reduced poverty. Similar to those expressed by Adams and Page [115] in their study, our findings demonstrate that remittances may be endogenous to poverty, which assumes that variations in poverty in developing countries cause changes in the level of remittances sent home by migrant workers. Particularly, we see stronger NRMT-POV links in lower-middle-income countries of Asia (Kyrgyzstan, Pakistan, India). However, the extent of endogeneity bias on poverty decreases in upper-middle-income economies, where NRMT-POV relationships are weaker (Belarus, Colombia, Paraguay) or even negligible (Brazil, Ecuador, Panama). According to Imai et al. [116], the fact that remittance flows have a positive effect on economic growth is robust to endogeneity concerns, but poverty reduction is not directly associated with economic growth. We have already addressed the issue of income inequality above.

Not all poor households receive remittances, and other factors must be meant by the government to efficiently alleviate poverty and reduce income inequality in rural areas. In this respect, the relationship between remittance inflows and foreign direct investment deserves particular consideration, because it could be assumed that increasing FDI inflows would help create more employment opportunities in rural areas, generate more income for poor rural dwellers, and thus prevent some of them from leaving the country in search of jobs abroad [117]. This, in turn, would decrease the inflow of remittances. In this study, we did not focus on investigating the links between independent variables NFDI and NRMT. For some developing economies, such links have been previously revealed by Muhammad and Kameyama [118] (in Philippines and India) and Orji et al. [119] (in Nigeria), but an inverse relationship between the increase in NFDI and decrease in NRMT hypothesized by us should be further tested in cases of lower-income and higher-income developing countries separately.

In addition to endogeneity changes depending on the level of economic development, some nuances were not properly addressed in our study. For instance, Musakwa and Odhiambo [120] discovered that foreign remittances have no short-run and long-run impact on poverty when poverty is measured by household consumption expenditure, while Mengistu and Ashagre [121] found that remittance inflows had a significant negative impact on poverty headcount due to higher transfer costs. These issues should be taken into account when studying the remittances-poverty relationship (most probably, by adjusting the set of explanatory variables and considering the mean value of household expenditures and the costs of money transfer from abroad).

\subsection{Model 2: Agriculture Development}

Model 2 results showed us that the value of agricultural trade flows had the strongest positive influence on the level of agricultural development. In upper-middle-income countries of Latin America, the causality link between the value of food trade and the level of agriculture development is stronger compared with that in lower-middle-income countries of Asia. For higher-income countries, agriculture development policies should involve stimulation of food exports and deeper inclusion in global food supply chains. In low-income countries, food supply in the poorest segments of society is for the most part ensured by local staple foods, whereas import is prohibitively expensive [3]. We see that 
with an increase in the level of income, the link between AGR from one side and AGRX and AGRM from the other becomes tighter. The revealed relationship would suggest that the development of the domestic agricultural sector in lower-income countries could be improved by stimulating and supporting local farmers to exports their products while implementing customs and tariff regulations of import. For agriculture development to become sustainable and contribute to the reduction of poverty in rural areas, it is imperative to develop production, logistics, and supply infrastructure [122]. Efforts aimed at encouraging the export of agricultural commodities in which a country enjoys a comparative advantage and easing import of those in which a country has a disadvantage could lead to the improved performance of the agricultural sector and more stable food supply for the poor.

Compared with trade inflows, foreign direct investment appeared to exert less significant influence on the development of the agricultural sector in the long term-perspective. Previously the impact of FDI on the sustainable growth of the host nation's agriculture was examined in terms of transfer of technologies and knowledge from developed countries to the developing world [105,123]. In virtue of technological abilities, knowledge, and experience of developed countries, investors offer learning opportunities and knowledge access to local sectors and, as an outcome, promote the growth of developing countries [124]. There has been evidence of how an inflow of investment from abroad promoted the growth of agricultural output in developing economies in both the short and long run. In general, policy recommendations for both lower-income and higher-income countries include an increase in the attraction of FDI in the agricultural sector. However, as opposed to Chaudhuri and Banerjee [66] and Kubik and Husmann [65], we did not record a strong link between NFDI and AGR variables. A weak relationship between investment and agriculture development was earlier reported by Idowu and Ying [11] and Ajuwon and Ogwumike [125] in the case of Nigeria, while Rufai and Celine [64] in their study of Nigeria's agriculture in 1960-2008 did not find any relationship between the two variables.

Similar to contradictory findings of FDI's influence on agriculture development in various countries, there has been no consensus about the impact of foreign aid on agricultural output. We revealed a positive, but weak link between AGR and NODA variables. This finding well agrees with Sethi et al. [126] who revealed insignificant impacts of foreign aid inflows on economic growth in India and Sri Lanka in both short-run and long-run perspectives. However, Sethi et al. [126] assumed that aid and development assistance tended to be more effective in countries with more developed economic policies and more sound public institutions. In lower-income countries, foreign aid inflows should be directed to the agricultural sector in the form of purchasing agricultural machinery, fertilizers, seeds, and other inputs. In higher-income countries, longer-term development programs aimed at the overall improvement of economic institutions would be more effective than a redirection of foreign aid into purchasing agricultural inputs from abroad. A tighter AGR-NODA link in upper-middle-income countries compared to lower-middle economies revealed by us actually bears out this guess. However, this hypothesis must be further tested on a wider array of countries with the inclusion of least developed and low-income economies. Strong effects of foreign aid on agriculture development have been revealed previously [36,37], but few studies have differentiated much between the short-term and long-term effects of the two variables. We also did not reveal substantial differences between AGR-NODA links in the short-term and long-term perspectives. However, this difference should be accounted for in future studies, since, for example, Amartey [87] evidenced a significant positive impact of foreign aid on agriculture development in the short run, but a negative one in the long run. This effect must be further checked in cases of various developing and least developed countries in Africa, Latin America, and Asia in a longer perspective.

According to our results, the impact of external debt on agriculture development is weak, but positive, which contradicts the majority of previous studies, including Ajayi and Oke [74], Mohd Dauda et al. [127], and Patillo et al. [77], among others. An increase in external debt could have an inverse relationship with agriculture productivity (for instance, 
reported by Ebhotemhen and Umoru [128]) and even result in lower agricultural output (found by Degu [129]). These results line up with previously discussed lower returns of aid for agricultural productivity in lower-income countries. A positive NEXD-AGR relationship revealed in our study is higher in upper-middle-income economies of Latin America and the Caribbean, but weaker in lower-middle-income countries of South Asia (particularly, Pakistan) and Central Asia (Kyrgyzstan). However, the fact is these are less developed countries that are more dependent on external borrowing to develop their economies, implement poverty alleviation programs, and develop the agricultural sector. Therefore, the NEXD-AGR relationship must be further tested on a wider array of countries by the expansion of the set of explanatory variables in the model, since governments could utilize external borrowing to finance anti-poverty, education, or health care programs or accelerate the development of the agricultural sector by investing in agricultural research and development.

It has been commonly accepted that remittances improve the wellbeing of poor people in rural areas $[78,80-82]$ and even contribute to the development of local agricultural production [79]. In our study, the net value of foreign remittances was found to exert a negative influence on domestic agriculture in lower-middle-income economies (primarily, in Kyrgyzstan and Pakistan), but neutral and even slightly positive (in the case of Belarus) impact on agriculture development in upper-middle-income countries. One of the suggested explanations of an inverse relationship between NRMT and AGR variables could be that the role of remittance inflows in agriculture productivity depends on the level of development of countries and regions, as well as individual characteristics of rural households and their consumption and investment behavior. One can expect that remittances benefit the families of migrant workers by increasing their ability to purchase capital goods and invest in the expansion of farming activities [130], but it is probably safe to assume that not all rural dwellers necessarily use capital inflows received from abroad on purchasing agricultural inputs [131,132]. Hence, an increase in remittance inflows does not directly transforms into higher output in agriculture. In support of this assumption, we can refer to the studies of Qin and Liao [133] and Taylor et al. [27], who both revealed the influence of regional divergences on the relationship between the value of foreign remittances, agriculture change, and regional growth. Moreover, remittance inflow usually directly correlates with the migration of labor from rural areas [27], which means that a higher value of remittances could be associated with a decrease in productive labor in agriculture in a home country. In lower-income countries, governments should be particularly oriented on the creation of jobs and employment opportunities in rural areas (including non-agricultural ones) to reduce the outflow of labor. Out-migration is one of the variables which could be included in the model in further studies as it allows explaining the variations of the NRMT-AGR relationship in lower-income and higher-income countries.

\section{Conclusions}

This paper investigated the effects of foreign capital inflows on poverty reduction and agriculture development in developing countries. We studied how the impacts of agricultural trade, foreign investment, foreign aid, external borrowing, and remittances on poverty and agricultural development could vary in lower-middle-income and uppermiddle-income economies. The study was conducted in cases of fourteen countries of Latin America and the Caribbean, East Asia and Pacific, South Asia, Central Asia, and Eastern Europe. The panel unit root test and the pool mean group estimation techniques were employed for observing the short-term and long-term linkages between dependent and explanatory variables.

The results of the Model 1 elaborate that poverty reduction is positively affected by an increase in the values of agricultural exports, foreign direct investment, foreign development assistance, and remittances received from migrant workers who support their families in home countries, while external debt and agriculture imports boost poverty in the region. It is main concern of the policymakers to alleviate poverty and enhance 
economic growth. The effective utilization of foreign resources can reduce poverty in developing countries where the contribution of the agricultural sector to the economy is significant. As regards the level of agriculture development, it is positively influenced by deeper integration of developing economies to global food supply chains as either suppliers or consumers of food and agricultural products, while an increase in the net value of remittances could be a sign of outflow of labor from domestic agriculture and a loss of production capacity.

In light of these findings, policy recommendations for poverty alleviation through foreign capital inflows should include a possible decrease of government borrowing from abroad, as well as the development of domestic agricultural production to reduce dependence on agricultural imports. Agriculture development can also be achieved by improving the quality of exports of agriculture products, usage of the latest production techniques, and efficient utilization of foreign resources (Table 6).

Revealed contradictions in the effects of explanatory variables on dependent parameters of poverty reduction and agricultural output (including the negative relationship between remittances and agriculture development, the positive effect of external debt on the agricultural production, and discrepancies between short-term and long-term effects of foreign aid on poverty) should be taken into account in future studies. An adjustment of the set of explanatory variables, which we were unable to make due to data limitations (availability of data on capital inflows in developing countries in 1990-2018) could explain some of the contradictions and thus enrich the literature. For instance, it is worthwhile studying the rationale of expanding the models by considering the mean value of household expenditures, the costs of money transfer from abroad, the number of education and health care programs financed from abroad, and the number of out-migrants from rural areas. A suggested inverse relationship between an increase in foreign investment and a decrease in the value of remittances should be tested in cases of lower-income and higher-income developing countries separately. Further research can be carried out to differentiate between the short-term and long-term effects of capital inflows on both agriculture development and poverty reduction and further test these effects on a wider array of developing and least developed countries in Africa, Latin America, and Asia in a longer perspective.

Table 6. Policy recommendations.

\begin{tabular}{|c|c|c|c|c|}
\hline \multirow[b]{2}{*}{ Capital Inflows } & \multicolumn{2}{|c|}{ Lower-Middle-Income Economies } & \multicolumn{2}{|c|}{ Upper-Middle-Income Economies } \\
\hline & Poverty Reduction & $\begin{array}{l}\text { Agriculture } \\
\text { Development }\end{array}$ & Poverty Reduction & $\begin{array}{l}\text { Agriculture } \\
\text { Development }\end{array}$ \\
\hline Agricultural export & \multicolumn{2}{|c|}{$\begin{array}{l}\text { Stimulate domestic farmers to export } \\
\text { their products }\end{array}$} & \multicolumn{2}{|c|}{$\begin{array}{l}\text { Increase export of products in which a country has } \\
\text { a comparative advantage }\end{array}$} \\
\hline Agricultural import & $\begin{array}{c}\text { Ensure a stable supply } \\
\text { of staple foods } \\
\text { from abroad }\end{array}$ & $\begin{array}{l}\text { Implement customs } \\
\text { and tariff regulations of } \\
\text { import of } \\
\text { non-staple foods }\end{array}$ & Decrease imports & $\begin{array}{l}\text { Liberalize import of } \\
\text { those products in } \\
\text { which a country has a } \\
\text { disadvantage }\end{array}$ \\
\hline $\begin{array}{l}\text { Official development } \\
\text { assistance }\end{array}$ & $\begin{array}{l}\text { Targeted short-term } \\
\text { poverty and hunger } \\
\text { relief programs }\end{array}$ & $\begin{array}{l}\text { Direct foreign aid } \\
\text { inflows to the } \\
\text { agricultural sector }\end{array}$ & \multicolumn{2}{|c|}{$\begin{array}{l}\text { Long-term development assistance programs to } \\
\text { stimulate structural and institutional reforms }\end{array}$} \\
\hline $\begin{array}{l}\text { Foreign direct } \\
\text { investment }\end{array}$ & \multicolumn{2}{|c|}{$\begin{array}{c}\text { Every possible attraction of foreign } \\
\text { direct investment }\end{array}$} & \multicolumn{2}{|c|}{ Increase the value of foreign direct investment } \\
\hline External debt & $\begin{array}{l}\text { Reduce the foreign debt } \\
\text { burden }\end{array}$ & $\begin{array}{l}\text { Direct borrowed funds } \\
\text { to the agricultural } \\
\text { sector }\end{array}$ & $\begin{array}{l}\text { Control foreign debt, } \\
\text { reduce when possible }\end{array}$ & $\begin{array}{l}\text { Utilize external } \\
\text { borrowing to accelerate } \\
\text { agricultural research } \\
\text { and development }\end{array}$ \\
\hline Remittances & $\begin{array}{l}\text { Liberalize incoming } \\
\text { money transfers and } \\
\text { out-migration policy }\end{array}$ & $\begin{array}{c}\text { Develop } \\
\text { non-agricultural } \\
\text { income opportunities } \\
\text { in rural areas }\end{array}$ & \multicolumn{2}{|c|}{$\begin{array}{l}\text { Easier currency controls and transfer of } \\
\text { remittances to the country }\end{array}$} \\
\hline
\end{tabular}


Author Contributions: H.W. and F.S. designed the research framework; H.W., F.S. and A.I. conceptualized the materials and methods; F.S. and S.R. performed the data collection; F.S., V.E. and A.I. analyzed the data; F.S. and V.E. wrote the paper. All authors have read and agreed to the published version of the manuscript.

Funding: This research is funded by Northeast Forestry University and Chinese Government Scholarship Council.

Institutional Review Board Statement: Not applicable.

Informed Consent Statement: Not applicable.

Data Availability Statement: The data presented in this study are available on request from the corresponding author.

Conflicts of Interest: The authors declare no conflict of interest.

\section{Appendix A}

Table A1. Models 1 and 2: short-run results 1990-2018.

\begin{tabular}{|c|c|c|}
\hline Variable & Model 1 & Model 2 \\
\hline \multirow[t]{3}{*}{ ECM } & $-0.517164 *$ & $-0.191722 * *$ \\
\hline & $(0.119188)$ & $(0.070949)$ \\
\hline & {$[-4.339079]$} & {$[-2.702227]$} \\
\hline \multirow[t]{3}{*}{$\mathrm{D}(\mathrm{POV}(-1))$} & -0.103544 & \\
\hline & $(0.132296)$ & \\
\hline & {$[-0.782675]$} & \\
\hline \multirow[t]{3}{*}{$\mathrm{D}(\mathrm{AGR}(-1))$} & & -0.021181 \\
\hline & & (0.072998) \\
\hline & & {$[-0.290160]$} \\
\hline \multirow{3}{*}{ D(NRMT) } & 0.003617 & 0.000797 \\
\hline & (0.003116) & $(0.000459)$ \\
\hline & [1.160767] & [1.736511] \\
\hline \multirow[t]{3}{*}{$\mathrm{D}(\mathrm{NRMT}(-1))$} & -0.000023 & 0.000524 \\
\hline & $(0.002316)$ & (0.000583) \\
\hline & {$[-0.010218]$} & [0.897551] \\
\hline \multirow[t]{3}{*}{$\mathrm{D}(\mathrm{NEXD})$} & 0.000742 & 0.000028 \\
\hline & (0.000517) & $(0.000125)$ \\
\hline & [1.436777] & [0.223008] \\
\hline \multirow[t]{3}{*}{$\mathrm{D}(\mathrm{NEXD}(-1))$} & -0.000082 & -0.000025 \\
\hline & $(0.000412)$ & $(0.000040)$ \\
\hline & {$[-0.199167]$} & {$[-0.628451]$} \\
\hline \multirow[t]{3}{*}{ D(NFDI) } & -0.000363 & -0.000088 \\
\hline & $(0.000844)$ & $(0.000074)$ \\
\hline & {$[-0.430635]$} & {$[-1.185398]$} \\
\hline \multirow[t]{3}{*}{ D(NFDI(-1)) } & -0.000824 & 0.000057 \\
\hline & (0.000927) & (0.000088) \\
\hline & {$[-0.888147]$} & [0.648854] \\
\hline \multirow[t]{3}{*}{ D(NODA) } & -0.004717 & 0.002790 \\
\hline & $(0.005168)$ & (0.001784) \\
\hline & {$[-0.912677]$} & [1.563985] \\
\hline \multirow[t]{3}{*}{ D(NODA(-1)) } & -0.012955 & 0.001777 \\
\hline & $(0.008811)$ & $(0.001441)$ \\
\hline & {$[-1.470248]$} & [1.233104] \\
\hline \multirow[t]{3}{*}{$\mathrm{D}(\mathrm{AGRX})$} & 0.898556 & 0.024026 \\
\hline & (1.033881) & (0.337296) \\
\hline & [0.869110] & [0.071231] \\
\hline \multirow[t]{2}{*}{$\mathrm{D}(\operatorname{AGRX}(-1))$} & -0.560253 & $-0.531221^{* *}$ \\
\hline & (2.172841) & $(0.316728)$ \\
\hline
\end{tabular}


Table A1. Cont.

\begin{tabular}{|c|c|c|}
\hline Variable & Model 1 & Model 2 \\
\hline \multirow{4}{*}{$\mathrm{D}(\mathrm{AGRM})$} & {$[-0.257843]$} & {$[-1.677213]$} \\
\hline & -0.564049 & 0.167391 \\
\hline & $(0.982705)$ & $(0.410363)$ \\
\hline & {$[-0.573976]$} & [0.407908] \\
\hline \multirow{3}{*}{$\mathrm{D}(\mathrm{AGRM}(-1))$} & 0.591774 & 0.063662 \\
\hline & (1.440119) & $(0.215781)$ \\
\hline & {$[0.410920]$} & {$[0.295031]$} \\
\hline \multirow[t]{3}{*}{$\mathrm{D}(\mathrm{GDPDF})$} & 0.117705 & \\
\hline & $(0.085734)$ & \\
\hline & [1.372909] & \\
\hline \multirow[t]{3}{*}{$\mathrm{D}(\mathrm{GDPDF}(-1))$} & $0.144515^{* *}$ & \\
\hline & $(0.082981)$ & \\
\hline & [1.741555] & \\
\hline \multirow[t]{3}{*}{ C } & -1.654841 & 0.425596 \\
\hline & $(1.302511)$ & $(0.726504)$ \\
\hline & {$[-1.270501]$} & {$[0.585814]$} \\
\hline Number of observations & 373 & 373 \\
\hline Time period & 26 years & 26 years \\
\hline Lag & 2 & 2 \\
\hline Sum of squared residuals & 0.938760 & 0.743812 \\
\hline Number of cross-sectional units & 14 & 14 \\
\hline
\end{tabular}

Note: ${ }^{*}$ significance at $5 \%$ level; ${ }^{* *}$ significance at $10 \%$ level; standard error is given in parenthesis; test statistic $t$ value is given in square brackets. Source: Authors' calculation.

\section{Appendix B}

Table A2. Robustness checks: long-run results of Model 1 and 2.

\begin{tabular}{|c|c|c|}
\hline Variable & Model 1 & Model 2 \\
\hline \multirow[t]{3}{*}{ NRMT } & $0.001368 *$ & $-0.001656^{*}$ \\
\hline & $(0.000249)$ & $(0.000203)$ \\
\hline & [5.489148] & {$[-8.158240]$} \\
\hline \multirow[t]{3}{*}{ NEXD } & $-0.000493 *$ & $0.001872 *$ \\
\hline & $(0.000099)$ & $(0.000358)$ \\
\hline & {$[-4.949628]$} & [5.227160] \\
\hline \multirow[t]{3}{*}{ NFDI } & $0.000202 *$ & 0.000035 \\
\hline & $(0.000031)$ & $(0.000335)$ \\
\hline & {$[6.458271]$} & [0.099902] \\
\hline \multirow[t]{3}{*}{ NODA } & $0.000657 *$ & 0.017920 * \\
\hline & $(0.000155)$ & $(0.002039)$ \\
\hline & [4.238700] & [8.786595] \\
\hline \multirow[t]{3}{*}{ AGRX } & 2.859920 * & 1.105843 * \\
\hline & $(0.571442)$ & $(0.442369)$ \\
\hline & [5.004745] & [2.499823] \\
\hline \multirow[t]{3}{*}{ AGRM } & $-0.488023^{*}$ & 2.086820 * \\
\hline & $(0.168560)$ & $(0.210226)$ \\
\hline & {$[-2.895247]$} & [9.92655] \\
\hline \multirow[t]{3}{*}{ GDPDF } & $0.001782 *$ & \\
\hline & $(0.000827)$ & \\
\hline & [2.155490] & \\
\hline \multirow[t]{3}{*}{ ECM } & $-0.476127^{*}$ & -0.219545 * \\
\hline & $(0.144474)$ & $(0.103131)$ \\
\hline & {$[-3.295596]$} & {$[-8.158240]$} \\
\hline Lag & 2 & 2 \\
\hline Number of observations & 238 & 238 \\
\hline Number of cross-sectional units & 9 & 9 \\
\hline
\end{tabular}

Note: ${ }^{*}$ significance at $5 \%$ level; standard error is given in parenthesis; test statistic $t$ value is given in square brackets. Source: Authors' calculation. 


\section{References}

1. United Nations. The 17 Goals. Available online: https://sdgs.un.org/goals (accessed on 5 December 2020).

2. Zhou, X.; Moinuddin, M.; Xu, M. Sustainable Development Goals Interlinkages and Network Analysis: A Practical Tool for SDG Integration and Policy Coherence; Institute for Global Environmental Strategies: Hayama, Japan, 2017.

3. Erokhin, V.; Gao, T. Impacts of COVID-19 on trade and economic aspects of food security: Evidence from 45 developing countries. Int. J. Environ. Res. Public Health 2020, 17, 5775. [CrossRef]

4. World Bank. Poverty and Shared Prosperity 2020: Reversals of Fortune; The World Bank: Washington, DC, USA, 2020.

5. Food and Agriculture Organization of the United Nations; International Fund for Agricultural Development; United Nations Children's Fund; World Food Programme; World Health Organization. The State of Food Security and Nutrition in the World 2019. Safeguarding against Economic Slowdowns and Downturns; FAO: Rome, Italy, 2019.

6. World Food Programme. COVID-19 Will Double Number of People Facing Food Crises Unless Swift Action Is Taken. Available online: https:/ / www.wfpusa.org/news-release/covid-19-will-double-number-of-people-facing-food-crises-unless-swiftaction-is-taken/ (accessed on 2 December 2020).

7. United Nations. Goal 1: End Poverty in All Its Forms Everywhere. Available online: https://sdgs.un.org/goals/goal1 (accessed on 2 December 2020).

8. United Nations. Goal 2: End Hunger, Achieve Food Security and Improved Nutrition and Promote Sustainable Agriculture. Available online: https:/ /sdgs.un.org/goals/goal2 (accessed on 5 December 2020).

9. Erokhin, V. Establishing Food Security and Alternatives to International Trade in Emerging Economies; IGI Global: Hershey, PA, USA, 2018. [CrossRef]

10. Ahmed, M.; Bhandari, H.; Gordoncillo, P.; Quicoy, C.; Carnaje, G. Factors affecting extent of rural livelihood diversification in selected areas of Bangladesh. Saarc J. Agric. 2018, 16, 7-21. [CrossRef]

11. Idowu, A.A.; Ying, L. An evaluation and forecast of the impact of foreign direct investment in Nigeria's agriculture sector in a VAR environment. J. Econ. Sustain. Dev. 2013, 10, 17-28.

12. Erokhin, V.; Gao, T. Handbook of Research on Globalized Agricultural Trade and New Challenges for Food Security; IGI Global: Hershey, PA, USA, 2020. [CrossRef]

13. Schultz, T.; The Economics of Being Poor. The Nobel Prize Lecture. Available online: https://www.nobelprize.org/prizes/ economic-sciences/1979/schultz/lecture/ (accessed on 5 December 2020).

14. Organisation for Economic Co-Operation and Development. OECD-FAO Agricultural Outlook 2014; OECD: Paris, France, 2014.

15. Ameh, O.E.; Sunday, O.A.; Baajon, M.A.; Chukwuemeka, N.J. An empirical analysis of the effect of agricultural input on agricultural productivity in Nigeria. Int. J. Agric. Sci. Food Technol. 2017, 3, 077-085. [CrossRef]

16. Food and Agriculture Organization of the United Nations. The State of Food Insecurity in the World 2006: Eradicating World Hunger-Taking Stock Ten Years after the World Food Summit; FAO: Rome, Italy, 2006.

17. Santangelo, G.D. The impact of FDI in land in agriculture in developing countries on host country food security. J. World Bus. 2018, 53, 75-84. [CrossRef]

18. Ssozi, J.; Asongu, S.; Amavilah, V.H. The effectiveness of development aid for agriculture in Sub-Saharan Africa. J. Econ. Stud. 2019, 46, 284-305. [CrossRef]

19. Arvin, B.M.; Barillas, F. Foreign aid, poverty reduction, and democracy. Appl. Econ. 2002, 34, 2151-2156. [CrossRef]

20. United Nations Conference on Trade and Development. Investment Policy Framework for Sustainable Development; UNCTAD: Geneva, Switzerland, 2015.

21. Institute of International Finance. Capital Flows to Emerging Markets Report. Available online: https://www.iif.com/Research/ Capital-Flows-and-Debt/Capital-Flows-to-Emerging-Markets-Report (accessed on 30 December 2020).

22. World Bank. Global Economic Prospect; The World Bank: Washington, DC, USA, 2014.

23. Petrikova, I. Aid for food security: Does it work? Int. J. Dev. Issues 2015, 14, 41-59. [CrossRef]

24. Slimane, M.B.; Huchet-Bourdon, M.; Zitouna, H. The role of sectoral FDI in promoting agricultural production and improving food security. Int. Econ. 2016, 145, 50-65. [CrossRef]

25. Magombeyi, M.; Odhiambo, N. FDI inflows and poverty reduction in Botswana: An empirical investigation. Cogent Econ. Financ. 2018, 6, 1480302. [CrossRef]

26. De Brauw, A. Seasonal migration and agricultural production in Vietnam. J. Dev. Stud. 2010, 46, 114-139. [CrossRef]

27. Taylor, J.E.; Rozelle, S.; De Brauw, A. Migration, remittances, and agricultural productivity in China. Am. Econ. Rev. 1999, 89, 287-291. [CrossRef]

28. Senadza, B.; Fiagbe, K.; Quartey, P. The effect of external debt on economic growth in Sub-Saharan Africa. Int. J. Bus. Econ. Sci. Appl. Res. 2017, 11, 61-69. [CrossRef]

29. Gupta, K.L. Foreign capital inflows, dependency burden and savings rates in developing countries: A simultaneous equation model. Kyklos 1975, 28, 358-374. [CrossRef]

30. Islam, A. Foreign aid and economic growth: An econometric study of Bangladesh. Appl. Econ. 1992, 24, 541-544. [CrossRef]

31. Levy, V. Aid and growth in Sub-Saharan Africa: The recent experience. Eur. Econ. Rev. 1988, 32, 1777-1795. [CrossRef]

32. Chong, A.; Gradstein, M.; Calderon, C. Can foreign aid reduce income inequality and poverty? Public Choice 2009, 140, 59-84. [CrossRef] 
33. Azam, M.; Haseeb, M.; Samsudin, S. The impact of foreign remittances on poverty alleviation: Global evidence. Econ. Sociol. 2016, 9, 264-281. [CrossRef] [PubMed]

34. Wrangberg, P. The Effect of Foreign Aid on Poverty; Erasmus University Rotterdam: Rotterdam, The Netherlands, 2018.

35. Burnside, C.; Dollar, D. Aid, Policies and Growth; The World Bank: Washington, DC, USA, 1997.

36. Kaya, O.; Kaya, I.; Gunter, L. Foreign aid and the quest for poverty reduction: Is aid to agriculture effective? J. Agric. Econ. 2013, 64, 583-596. [CrossRef]

37. Mary, S.; Shaw, K.; Colen, L.; Paloma, S.G. Does agricultural aid reduce child stunting? World Dev. 2020, 130, 104951. [CrossRef]

38. Philip, O.O. Foreign aid and poverty level in West African countries: New evidence using a heterogeneous panel analysis. Aust. J. Bus. Manag. Res. 2013, 3, 9-18.

39. Ijaiya, G.T.; Ijaiya, M.A. Foreign aid and poverty reduction in Sub-Saharan Africa: A cross-country investigation. S. Afr. J. Econ. Manag. Sci. 2004, 7, 542-552. [CrossRef]

40. Bauer, P.T. The Development Frontier: Essays in Applied Economics; Harvard University Press: Cambridge, MA, USA, 1991.

41. Fofana, K.H.; Xia, E.; Traore, M.B. Dynamic relationship between Chinese FDI, agricultural and economic growth in West African: An application of the pool mean group model. Iop Conf. Ser. J. Phys. Conf. Ser. 2018, 1060, 012066. [CrossRef]

42. Ikenze, F.I.; Aondokaa, K.E.; Ogbonna, K.S.; Adoms, F.U. FDI and Economic Growth in Developing African Economy: A Study of FDI Inflows to Different Sectors of Nigeria. Discovery 2020, 56, 313-320.

43. Kumar, M.A.; Gopalsamy, S. Agricultural sector FDI and economic growth in SAARC countries. Int. J. Recent Technol. Eng. 2019, 8, 116-121. [CrossRef]

44. Gohou, G.; Soumaré, I. Does foreign direct investment reduce poverty in Africa and are there regional differences? World Dev. 2012, 40, 75-95. [CrossRef]

45. Huang, C.-H.; Teng, K.-F.; Tsai, P.-L. Inward and outward foreign direct investment and poverty: East Asia vs. Latin America. Rev. World Econ. 2010, 146, 763-779. [CrossRef]

46. Williamson, J. The Management of Capital Inflows. Available online: https://www.piie.com/commentary/speeches-papers/ management-capital-inflows (accessed on 30 December 2020).

47. Reyer, C.; Otto, I.; Adams, S.; Albrecht, T.; Baarsch, F.; Cartsburg, M.; Coumou, D.; Eden, A.; Ludi, E.; Marcus, R.; et al. Climate change impacts in Central Asia and their implications for development. Reg. Environ. Chang. 2017, 17, 1639-1650. [CrossRef]

48. World Trade Organization. Members Discuss Impact of COVID-19 on Developing Economies' Participation in World Trade. Available online: https://www.wto.org/english/news_e/news20_e/devel_26may20_e.htm (accessed on 2 December 2020).

49. World Trade Organization. The COVID-19 Pandemic and Trade-Related Developments in LDCs. Available online: https: //www.wto.org/english/tratop_e/covid19_e/ldcs_report_e.pdf (accessed on 2 December 2020).

50. Deuss, A. Impact of Agricultural Export Restrictions on Prices in Importing Countries; OECD Publishing: Paris, France, 2017.

51. Martin, W.; Anderson, K. Export Restrictions and Price Insulation during Commodity Price Booms; The World Bank: Washington, DC, USA, 2011.

52. Hendrix, C.S. Wrong Tools, Wrong Time: Food Export Bans in the Time of COVID-19. Available online: https://www.piie. $\mathrm{com} / \mathrm{blogs} /$ realtime-economic-issues-watch/wrong-tools-wrong-time-food-export-bans-time-covid-19 (accessed on 2 December 2020).

53. Huseynov, R. Multidimensional determinants of national food security in Azerbaijan: An application of the ARDL approach. Zesz. Nauk. Sggw W Warszawie Probl. Rol. Światowego 2019, 19, 58-68. [CrossRef]

54. Puma, M.; Bose, S.; Chon, S.Y.; Cook, B. Assessing the evolving fragility of the global food system. Environ. Res. Lett. 2015, 10, 024007. [CrossRef]

55. Bahmani-Oskooee, M.; Oyolola, M. Poverty reduction and aid: Cross-country evidence. Int. J. Sociol. Soc. Policy 2009, 29, 264-273. [CrossRef]

56. Arndt, C.; Jones, S.; Tarp, F. Assessing foreign aid's long-run contribution to growth and development. World Dev. 2015, 69, 6-18. [CrossRef]

57. Mahembe, E.; Odhiambo, N.M. Does Foreign Aid Reduce Poverty in Sub-Saharan Africa? A Dynamic Panel-Data Analysis; University of South Africa: Pretoria, South Africa, 2018.

58. Herdt, R.W. Development aid and agriculture. In Handbook of Agricultural Economics; Evenson, R., Pingali, P., Eds.; Elsevier: Amsterdam, The Netherlands, 2010; pp. 3253-3304.

59. Janaiah, A.; Hossain, M.; Otsuka, K. Productivity impact of the modern varieties of rice in India. Dev. Econ. 2006, 44, 190-207. [CrossRef]

60. Rozelle, S.; Jin, S.; Huang, J.; Hu, R. The impact of investments in agricultural research on total factor productivity in China. In Crop Variety Improvement and Its Effect on Productivity: The Impact of International Agricultural Research; Evenson, R.E., Gollin, D., Eds.; CABI Publishing: Oxon, UK, 2003; pp. 361-386.

61. Maxwell, S. Six characters (and a few more) in search of an author: How to rescue rural development before it's too late. Agric. Econ. 2005, 32, 61-73. [CrossRef]

62. World Bank. World Development Report 2008: Agriculture for Development; The World Bank: Washington, DC, USA, 2007.

63. Abdullah, S. Agriculture and growth: Does foreign direct investment matters? Ucp Manag. Rev. 2018, 2, 63-74.

64. Rufai, O.; Celine, K. Causal relations between foreign direct investment in agriculture and agricultural output in Nigeria. Afr. J. Agric. Res. 2013, 17, 1693-1699. [CrossRef] 
65. Kubik, Z.; Husmann, C. Determinants of foreign direct investment in the African food and agriculture sector. In Proceedings of the 6th African Conference of Agricultural Economists, Abuja, Nigeria, 23-26 September 2019; African Association of Agricultural Economists: Abuja, Nigeria, 2019.

66. Chaudhuri, S.; Banerjee, D. FDI in agricultural land, welfare and unemployment in a developing economy. Res. Econ. 2010, 64, 229-239. [CrossRef]

67. Nedumaran, G.; Manida, M. Impact of FDI in agriculture sector in India: Opportunities and challenges. Int. J. Recent Technol. Eng. 2019, 8, 380-383. [CrossRef]

68. Li, Q.; Wahl, T. Efficiency and technological progress in the Chinese agriculture: The role of foreign direct investment. In Proceedings of the American Agricultural Economics Association Annual Meetings, Denver, CO, USA, 1-4 August 2004; American Agricultural Economics Association: Denver, CO, USA, 2004.

69. Hsiao, F.S.; Hsiao, M.-C.W. FDI, exports, and GDP in East and Southeast Asia-Panel data versus time-series causality analyses. J. Asian Econ. 2006, 17, 1082-1106. [CrossRef]

70. Magombeyi, M.T.; Odhiambo, N.M. Dynamic impact of FDI inflows on poverty reduction: Empirical evidence from South Africa. Sustain. Cities Soc. 2018, 39, 519-526. [CrossRef]

71. Ali, M.; Nishat, M. Do foreign inflows benefit Pakistani poor? Pak. Dev. Rev. 2009, 48, 715-738. [CrossRef]

72. Harris, R.; Sollis, R. Applied Time Series Modelling and Forecasting; Wiley: Hoboken, NJ, USA, 2003.

73. Krugman, P.R. Financing vs. Forgiving a Debt Overhang; National Bureau of Economic Research: Cambridge, MA, USA, 1988.

74. Ajayi, L.B.; Oke, M.O. Effect of external debt on economic growth and development of Nigeria. Int. J. Bus. Soc. Sci. 2012, 12, 297-304.

75. Siddique, A.; Selvanathan, E.; Selvanathan, S. The Impact of External Debt on Economic Growth: Empirical Evidence from Highly Indebted Poor Countries; University of Western Australia: Perth, Australia, 2015.

76. Deaton, A. Inequalities in Income and Inequalities in Health; National Bureau of Economic Research: Cambridge, MA, USA, 1999.

77. Patillo, H.; Poirson, H.; Ricci, L. External Debt and Growth and What Are the Channels through Which External Debt Affects Growth; International Monetary Fund: Washington, DC, USA, 2002.

78. Nwaogu, U.G.; Ryan, M.J. FDI, foreign aid, remittance and economic growth in developing countries. Rev. Dev. Econ. 2015, 19, 100-115. [CrossRef]

79. Chiodi, V.; Jaimovich, E.; Montes-Rojas, G. Migration, remittances and capital accumulation: Evidence from rural Mexico. J. Dev. Stud. 2012, 48, 1139-1155. [CrossRef]

80. Amuedo-Dorantes, C.; Pozo, S. Migration, remittances, and male and female employment patterns. Am. Econ. Rev. 2006, 96, 222-226. [CrossRef]

81. Gustafsson, B.; Makonnen, N. Poverty remittances in Lesotho. J. Afr. Econ. 1993, 2, 49-73. [CrossRef]

82. Du, Y.; Park, A.; Wang, S. Migration and rural poverty in China. J. Comp. Econ. 2005, 33, 688-709. [CrossRef]

83. Khanal, U.; Alam, K.; Khanal, R.C.; Regmi, P.P. Implications of out-migration in rural agriculture: A case study of Manapang Village, Tanahun, Nepal. J. Dev. Areas 2015, 49, 331-352. [CrossRef]

84. Thieme, S.; Wyss, S. Migration patterns and remittance transfer in Nepal: A case study of Sainik Basti in Western Nepal. Int. Migr. 2005, 43, 59-98. [CrossRef]

85. Wagle, U.R.; Devkota, S. The impact of foreign remittances on poverty in Nepal: A panel study of household survey data, 1996-2011. World Dev. 2018, 110, 38-50. [CrossRef]

86. Vargas, L.; Villarreal, M.; Lanly, G.; Osorio, M. International Migration, Remittances and Rural Development; International Fund for Agricultural Development: Rome, Italy, 2008.

87. Amartey, D. The Effect of Foreign Aid on Agriculture, Education and Health Sectors in Ghana; University of Ghana: Accra, Ghana, 2015.

88. Verbeek, M. A Guide to Modern Econometrics; John Wiley \& Sons: Chichester, UK, 2004.

89. Pesaran, M.H.; Shin, Y.; Smith, R.P. Pooled mean group estimation of dynamic heterogeneous panels. J. Am. Stat. Assoc. 1999, 446, 621-634. [CrossRef]

90. Levin, A.; Lin, C.F.; Chu, C.S.J. Unit root tests in panel data: Asymptotic and finite-sample properties. J. Econom. 2002, 108, 1-24. [CrossRef]

91. Das, D.K. Determinants of current account imbalance in the global economy: A dynamic panel analysis. Econ. Struct. 2016, 5, 8. [CrossRef]

92. Im, K.S.; Pesaran, M.H.; Shin, Y. Testing for unit roots in heterogeneous panels. J. Econom. 2003, 115, 53-74. [CrossRef]

93. Gujarati, D.N. Basic Econometrics; Tata McGraw Hill: New Delhi, India, 2004.

94. World Bank. World Development Indicators. Available online: https://databank.worldbank.org/source/world-developmentindicators (accessed on 2 December 2020).

95. EconData. Penn World Table. Available online: https:// econdata.com/dbinfo/outline/pwt/ (accessed on 2 December 2020).

96. World Bank. World Bank Country and Lending Groups. Available online: https://datahelpdesk.worldbank.org/knowledgebase/ articles /906519-world-bank-country-and-lending-groups (accessed on 29 December 2020).

97. Aronu, C.O.; Arhovwon, L.O.; Emunefe, J.O.; Ekwueme, G.O.; Otty, N.U. On the determinants of economic openness in Nigeria. Asian J. Econ. Bus. Account. 2020, 18, 42-53. [CrossRef]

98. Aslam, M.A.L.; Lebbe, A.S.M. Inflation and economic growth in Sri Lanka: An ARDL bound testing approach. In Proceedings of the South Eastern University Arts Research Session-2016; South Eastern University of Sri Lanka: Oluvil, Sri Lanka, 2016. 
99. Iqbal Chaudhry, N.; Mehmood, A.; Saqib Mehmood, M. Empirical relationship between foreign direct investment and economic growth: An ARDL Co-integration approach for China. China Financ. Rev. Int. 2013, 3, 26-41. [CrossRef]

100. Mehrara, M. Return predictability of stock price index in Tehran stock exchange. Int. Lett. Soc. Humanist. Sci. 2013, 9, 59-64. [CrossRef]

101. Badshah, W.; Bulut, M. Model selection procedures in bounds test of cointegration: Theoretical comparison and empirical evidence. Economies 2020, 8, 49. [CrossRef]

102. Wood, S.A.; Smith, M.R.; Fanzo, J.; Remans, R.; DeFries, R.S. Trade and the equitability of global food nutrient distribution. Nat. Sustain. 2018, 1, 34-37. [CrossRef]

103. Mouloudj, K.; Bouarar, A.C.; Fechit, H. The impact of COVID-19 pandemic on food security. Les Cah. Du Cread 2020, 36, 159-184.

104. Toffolutti, V.; Stuckler, D.; McKee, M. Is the COVID-19 pandemic turning into a European food crisis? Eur. J. Public Health 2020, 30, 626-627. [CrossRef]

105. Elbadawi, I.; Ndulu, B.J.; Ndung'u, N. Debt overhang and economic growth in Sub-Saharan Africa. In External Finance for Low-Income Countries; Iqbal, Z., Kanbur, R., Eds.; International Monetary Fund: Washington, DC, USA, 1997; pp. 49-76.

106. Were, M. The Impact of External Debt on Economic Growth in Kenya: An Empirical Assessment; World Institute for Development Economic Research: Helsinki, Finland, 2001.

107. Nguyen, T.Q.; Clements, M.B.J.; Bhattacharya, M.R. External Debt, Public Investment, and Growth in Low-Income Countries; International Monetary Fund: Washington, DC, USA, 2003.

108. Ashraf, M.W.; Akhtar, M.J.; Hafeez-ul-Rehman, P.; Awan, A.G. Impact of external debt on poverty in Pakistan. Glob. J. Manag. Soc. Sci. Humanit. 2020, 6, 251-271.

109. Ucal, M.Ş. Panel Data analysis of foreign direct investment and poverty from the perspective of developing countries. Procedia-Soc. Behav. Sci. 2014, 109, 1101-1105. [CrossRef]

110. Ahmad, F.; Draz, M.U.; Su, L.; Ozturk, I.; Rauf, A.; Ali, S. Impact of FDI inflows on poverty reduction in the ASEAN and SAARC economies. Sustainability 2019, 11, 2565. [CrossRef]

111. Alhamad, M.; Ahmed, A. The effect of foreign aid on poverty reduction in developing countries. In Proceedings of the XIX International Conference, Boston Conference Series, Boston, MA, USA, 18-22 August 2018.

112. Ogbodo, J.C.; Attamah, N. Analysis of the impact of foreign aid on poverty reduction in Nigeria, 1981-2017. Esut J. Soc. Sci. 2019, 4, 120-139.

113. Ugwuanyi, U.B.; Ezeaku, H.C.; Ibe, I.G. The impact of official aid on poverty reduction: Empirical evidence from Nigeria (1981-2014) using the ARDL and bound test approach. Eur. J. Sustain. Dev. 2017, 6, 111-120. [CrossRef]

114. Boone, P. Politics and the effectiveness of foreign aid. Eur. Econ. Rev. 1996, 40, 289-329. [CrossRef]

115. Adams, R.H.; Page, J. Do international migration and remittances reduce poverty in developing countries? World Dev. 2005, 33, 1645-1669. [CrossRef]

116. Imai, K.S.; Gaiha, R.; Ali, A.; Kaicker, N. Remittances, growth and poverty: New evidence from Asian countries. J. Policy Modeling 2014, 36, 524-538. [CrossRef]

117. Wang, M.; Wong, S.M.C. Inward FDI, remittances, and out-migration. Appl. Econ. Lett. 2011, 18, 1405-1409. [CrossRef]

118. Muhammad Al, M.; Kameyama, Y. Effects of FDI and remittances on the international migration and tourism from Asian countries to Japan. Jpn. Soc. Innov. J. 2019, 9, 1-19. [CrossRef]

119. Orji, A.; Ogbuabor, J.E.; Nwosu, E.; Anthony-Orji, O.I.; Okpala, A.J. FDI, remittance inflows, and economic development in a developing economy: What do Nigerian data show? J. Acad. Res. Econ. 2019, 11, 27-45.

120. Musakwa, M.T.; Odhiambo, N. The impact of remittance inflows on poverty in Botswana: An ARDL approach. J. Econ. Struct. 2019, 8, 42. [CrossRef]

121. Mengistu, Y.A.; Ashagre, E. The Effect of Personal Remittance on Poverty Reduction in Sub Saharan Africa. Available online: https: / / papers.ssrn.com/sol3/papers.cfm?abstract_id=3307769\# (accessed on 1 December 2020).

122. Erokhin, V.; Li, D.; Du, P. Sustainability-related implications of competitive advantages in agricultural value chains: Evidence from Central Asia-China trade and investment. Sustainability 2020, 12, 1117. [CrossRef]

123. Meyer, K.E.; Sinani, E. When and where does foreign direct investment generate positive spillovers? A Meta-Analysis. J. Int. Bus. Stud. 2009, 40, 1075-1094. [CrossRef]

124. Blomström, M.; Kokko, A. Multinational corporations and spillovers. J. Econ. Surv. 1998, 12, 247-277. [CrossRef]

125. Ajuwon, O.; Ogwumike, F. Uncertainty and foreign direct investment: A case of agriculture in Nigeria. Mediterr. J. Soc. Sci. 2013, 4, 155. [CrossRef]

126. Sethi, N.; Bhujabal, P.; Das, A.; Sucharita, S. Foreign aid and growth nexus: Empirical evidence from India and Sri Lanka. Econ. Anal. Policy 2019, 64, 1-12. [CrossRef]

127. Mohd Dauda, S.N.; Ahmad, A.H.; Azman-Saini, W. Does external debt contribute to malaysia economic growth? Econ. Res. Ekon. Istraživanja 2013, 26, 51-68. [CrossRef]

128. Ebhotemhen, W.; Umoru, D. External debt and agricultural production in Nigeria. Sriwij. Int. J. Dyn. Econ. Bus. 2019, 3, 1-14. [CrossRef]

129. Degu, A.A. Analysis of factors affecting agricultural output growth in Ethiopia: Macro-economic perspective. Res. Agric. Vet. Sci. 2019, 3, 152-167. 
130. Mochebelele, M.T.; Winter-Nelson, A. Migrant labor and farm technical efficiency in Lesotho. World Dev. 2000, $28,143-153$. [CrossRef]

131. Tuladhar, R.; Sapkota, C.; Adhikari, N. Effects of Migration and Remittance Income on Nepal's Agriculture Yield; Asian Development Bank: Manila, Philippines, 2014.

132. Piras, S.; Vittuari, M.; Möllers, J.; Herzfeld, T. Remittance inflow and smallholder farming practices. The case of Moldova. Land Use Policy 2018, 70, 654-665. [CrossRef]

133. Qin, H.; Liao, T.F. Labor out-migration and agricultural change in rural China: A systematic review and meta-analysis. J. Rural Stud. 2016, 47, 533-541. [CrossRef] 